DOI: $10.17516 / 1997-1370-0528$

УДК 33.2064

\title{
Economic Nature of the Phenomenon "Freebie" in Russian Student Community
}

\author{
Marina V. Ryzhkovaa,b and Darja V. Alimovab \\ ${ }^{a}$ National Research Tomsk State University \\ Tomsk, Russian Federation \\ ${ }^{b}$ National Research Tomsk Polytechnic University \\ Tomsk, Russian Federation
}

Received 10.04.2019, received in revised form 20.11.2019, accepted 09.12.2019

\begin{abstract}
The article is devoted to the problems of behavioral economics in terms of formation of the attitude and perception of goods with zero price in their special form "freebie" (or in Russian - "haljava") as a special form of free (or almost free) good. The study showed the relationship between economic and non-economic goods. The definition of "freebie" is given as a situation of receiving a good in which an individual (recipient) bears zero or insignificant (inconspicuous) economic or physical costs with a perceived high assessment of the usefulness of the good. Three situations were considered: the recipient of a good is a consumer, an employee and a special case of employee - a student obtaining grades in the educational process. Market surpluses in these situations were analyzed in terms of "freebie" and "pure freebie". An in-depth interview was conducted among students which revealed that $95 \%$ of respondents drew a parallel between "freebie" and luck but "freebie" can be prepared to. An interesting finding is the fact that parents' money is perceived starting from the third year as a "freebie", while in younger courses it perceived as the help of parents. When studying the issue of morality in a situation "freebie", it turned out that if a "freebie" does not harm anyone, then this phenomenon is allowed and, moreover, is compared with entrepreneurial activity. Such phenomena as "free money" and "freeloader" as a stable "free" strategy were also analyzed. The latter was negatively judged by respondents. In conclusion, questions are raised for further research of the phenomenon.
\end{abstract}

Keywords: Behavioral economics, economic goods, non-economic goods, free goods, "freebie", "freeloader", economic costs, market surplus, morality, ethics.

Research area: economics.

Citation: Ryzhkova, M.V., Alimova, D.V. (2020). Economic nature of the phenomenon "freebie" in Russian student community. J. Sib. Fed. Univ. Humanit. Soc. Sci., 13(4), 591-599. DOI: 10.17516/19971370-0528.

\footnotetext{
(C) Siberian Federal University. All rights reserved

* Corresponding author E-mail address: marybox@inbox.ru ORCID: 0000-0002-0107-8016 (Ryzhkova)
} 


\section{Introduction}

Traditionally, in economic theory all goods are divided into economic and free. Free goods are characterized by accessibility without perceived restrictions. In another way, the market for such goods is absent due to their prevalence above their existing demand. The opportunity costs of production and consumption of such goods are also equal to zero. The assertion should be considered as a mistake that free goods do not have the properties of rarity. Reproducible free goods are self-reproducing at a rate exceeding the rate of their economic use, non-reproducible ones have such a level of supply that provides consumption for many years in advance. But this does not mean that the goods are infinitely accessible. There is no point in producing free goods, because their offer is so great that no one is going to pay for them, and, as a result, their price is zero.

In the search for examples of absolutely free goods (Brynjolfsson et al., 2019; Gal \& Rubinfeld, 2016), a researcher inevitably stumbles upon a difficulty, because there are no uniquely free goods, or, in other words, at the same time the goods can be both economic and free. For example, in economic theory sunlight is treated as a free good, but why then do consumers pay for visiting a solarium? Often a consumer would like to get rid of free goods and is willing to pay for it. In this case, getting rid of a free anti-good (such as mosquitoes in the open air) is in itself a blessing and also rare for which the consumer is willing to pay.

Most of the goods that are in demand by society are economic ones. A good is economic or rare if its required quantity as a free good exceeds its available free offer (Bronfenbrenner, 1962). For the production of an economic good, it is required to abandon the production of other goods and redirect limited resources to the required good. That is why economic goods have a value associated with the need to reimburse the cost of reproduction (for reproducible resources) or rent (for non-reproducible resources).

Under ordinary conditions, the price of the economic good is set in the positive area of the axes of prices, however, there are situations where it can be set at zero level. In fact, in very rare cases, the price may fall even below the zero level, which means that the consumer will be paid extra for getting rid of the goods. The situation is rare, but in principle conceivable, especially considering costs of storing goods or the opportunity cost of the area of storage facilities. However, this state of business is not normal, but rather a combination of unfortunate circumstances, or an entrepreneurial mistake.

During market competition, buyers are interested in lowering prices, a special case of this process is a zero price condition.

This paper is devoted to answering questions concerning characteristics of a situation when zero price for a product is a nonrandom phenomenon.

In 2007, Dan Ariely published a paper "Zero as a Special Price: The True Value of Free Products" (Ariely, 2007), where he describes the characteristics of the demand for goods with zero price. As a part of the research, he conducted a series of experiments, as a result of which comes the following conclusion: the demand for the good "overreact" to a decrease in the price from its minimum value (for example, 1 cent) to zero. Even when prices for other goods are reduced much more significantly (for example, from 15 to 10 cents) than the price of a "free" product (for example, from 1 cent to 0 ), the experiment participants prefer a product with a zero price. That is, for people, a product with a zero price ("pure freebie" in our further terminology) acquires additional value. D. Ariely offers a number of psychological explanations for this process. First, the receipt of "freebies" is not regulated by the market, but by the laws of social exchange (Heyman, Ariely 2004). Secondly, individuals have difficulty translating the value of the good's value into money, the case of free facilitates this process. Thirdly, chargeless evokes positive emotions that add utility to good.

It is worth noting that the approach of D. Ariel is unique. In Russian and international studies, free goods or economic goods, but sold at a zero price, fall outside the range of vision of researchers due to the lack of a positive economic effect from the production of such goods (in other words, the production of goods sold at 
a zero price means a systematic loss that contradicts the aim of entrepreneurship). However, if the phenomenon exists, then it makes sense.

Firstly, free goods can be made economic by limiting their supply, and it facilitates the formation of a new market in which for some time a situational monopoly will arise, which will induce an economic profit in the short run.

Secondly, economic goods sold at a zero price also induce a positive effect for producer. They help in entering a new market or redistributing shares in an existing market. The perfect mastership in managing consumer market behavior is the creation of a situation where the consumer, at a formally zero price of the product, reimburses its producer not only for costs, but also gives a net positive effect in some cases - profit. It is worth mentioning that in the previous situation, the calculation of the full price (including not only the amount indicated on the price tag, but also the total costs incurred by the consumer in connection with the purchase of the "free" good) is meant.

Since the consumer is not always cognitively able to perceive the full price of the product, the consumer's desire to "buy" the product at zero price is very strong.

\section{Theoretical framework: "freebie" as an economic phenomenon}

Here the concepts necessary for further discussion will be defined. In economic terminology (as in the terminology of related social disciplines) there is no special word for the situation of obtaining goods at zero price. In youth slang there is an established name for such situations - "freebie" (or in Russian - "haljava"). Based on the etymology of the word "freebie" (as well as the definitions given by answers of our respondents), we can conclude that "free-
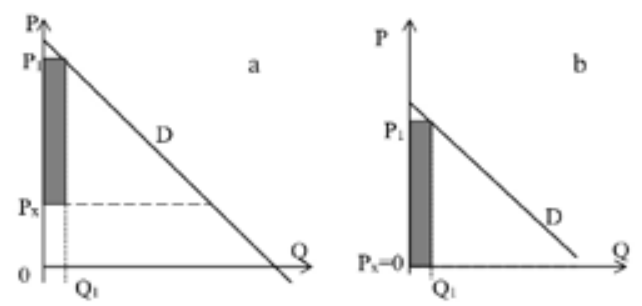

Fig. 1. "Freebie" as a consumer surplus bie" is a situation of receiving a good in which an individual (recipient) bears zero or insignificant (inconspicuous) economic or physical costs with a perceived high assessment of the usefulness of the good (see Chto oznachaet slovo "xali ava», 2017; Helemendrick, 2008).

There are two situations of obtaining a "freebie".

1) The recipient of a good is a consumer. He demands for the good and buys it at zero price.

2) The recipient is an employee, makes a labor offer and receives remuneration for it. In this case, with a zero level of effort, he receives a significant reward. A special case is the situation with obtaining grades in the educational process.

In each of the situations, we consider the general case when there is a compensation payment by the recipient, i.e. the price or level of effort is different from zero (Fig. 1a, 2a, 3a) and a special case ("pure freebie"), when the recipient does not contribute anything for the goods (Fig. 1b, 2b, 3b).

To analyze the first case in economic theory, there is an instrument of consumer surplus. The consumer is ready to pay the price for the product $\left(\mathrm{P}_{1}\right)$, but will not do it if it is possible to buy it at a lower price $\left(\mathrm{P}_{\mathrm{x}}\right.$; Fig. 1a) or even get it for free $\left(\mathrm{P}_{\mathrm{x}}=0\right.$; Fig. 1b).

The second case means obtaining "free earnings" as a producer surplus. In the perception of respondents, "free money" or "easy money" is, firstly, money received in a very simple way with minimal effort; secondly, the positive difference between the amount that they are promised to get (or the students expected to receive) and the amount that they actually get; thirdly, the additional
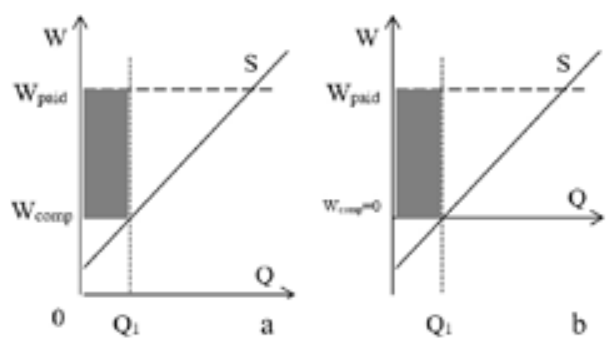

Fig. 2. "Freebie" as a producer surplus 
unexpected bonus for the work done earlier and the main payment for which has already been received.

Graphically, "free earnings" is a positive difference between the fee for labor efforts paid $\left(\mathrm{W}_{\text {paid }}\right)$ and the minimum necessary and "honest" compensation from the recipient's point of view $\left(\mathrm{W}_{\text {comp }}\right)$, which is shown in Fig. 2a. If the recipient did nothing at all (his labor efforts are zero, Fig. 2b), he is unlikely to refuse the payment.

"Freebie" in the educational process ("student freebie") is a producer surplus. The student makes an effort that is assessed by the teacher. It is possible both a situation of underpayment for the efforts spent to prepare for the exam (usually causing violent negative emotions) and overpayments (in this case, emotions are no less strong, but carefully hidden in fear of revealing your real level of knowledge and thereby lower the grade). The latter is a "freebie" situation. So, in accordance with Fig. 3a, the student spent on preparing for the exam efforts to calculate it for the satisfactory mark $\left(\mathrm{Q} \in\left(\mathrm{Q}_{3}, \mathrm{Q}_{4}\right)\right)$, but quite unexpectedly (s)he received an excellent mark. Even more fun is getting an excellent mark without any effort at all $\left(\mathrm{Q} \in\left(0, \mathrm{Q}_{3}\right)\right.$, Fig. 3b).

Of particular note is the measurement of the "freebie" value, which graphically represents the area of the shaded rectangles in Fig. 1, 2 and 3. However, due to the fact that $\mathrm{P}_{1}$ and $\mathrm{W}_{\text {comp }}$ are psychologically determined estimates, the determination of the "freebie" value in different situations is a scientific and practical problem. It is necessary to make a remark regarding the conventionality of the above figures containing graphs that clearly show the "freebie" value. The fact is that, in accordance with the results of D. Ariely, the value of a freebie is estimated by the consumer at a higher utility per ruble of savings than the utility per ruble of the price paid for the product, which means that not all of the surplus is shown on the graphs. Sales promotion specialists have long understood this fact and are using these behavioral features when conducting product presentations, distributing samplers, giving gifts, etc. Often, the monetary effect of revenue growth from such events exceeds not only their costs, but also turns out to be more effective than large-scale and expensive advertising companies.

An alternative approach to determining the size of a "freebie" is an excessive compensation (Shmakov, Bulgakova, 2011). In accordance with the risk neutrality approach, compensation should fully compensate for the loss.

Or return the consumer to the original indifference curve. Damage can be understood as all the cases described above, namely: the loss of another good (in the particular case, money) owned by the consumer, as well as the spent efforts of the consumer (as the cost of labor expended).

In accordance with Fig. 4a, damage $\left(\mathrm{Q}_{\mathrm{A} 1}-\right.$ $\mathrm{Q}_{\mathrm{A} 2}$ ) can be compensated by the provision of goods $B$ in the amount of $\left(Q_{B 1}-Q_{B 2}\right)$, which corresponds to fair compensation, as well as in the amount of $\left(\mathrm{Q}_{\mathrm{B1}}-\mathrm{Q}_{\mathrm{B} 3}\right)$, where part $\left(\mathrm{Q}_{\mathrm{B} 2}-\mathrm{Q}_{\mathrm{B} 3}\right)$ is a "freebie" and corresponds to the general case. Fig. $4 \mathrm{~b}$ shows the case of a "pure freebie" when the recipient did not lose anything and receives the benefit of B for free.

The approach to measuring the utility of a good to describe the receipt of goods with a zero price is not suitable due to the inability to evaluate utility using any of the existing methods (Ryzhkova, 2013), because the zero price does not allow to reach the optimum.
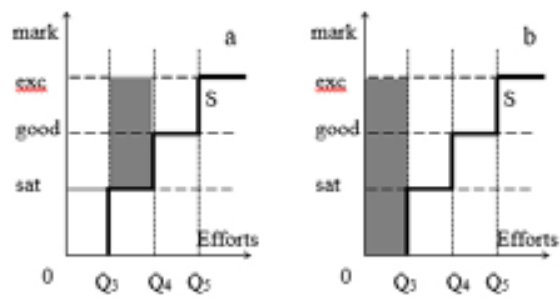

Fig. 3. "Freebie" in learning process
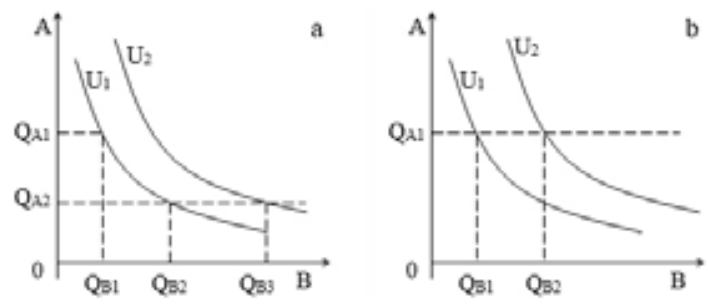

Fig. 4. The method of neutrality to risk and "freebie" 


\section{Methods}

This paper contains results of an in-depth interview of students of different courses in economic specialties of the National Research Tomsk Polytechnic University regarding their perception of the phenomenon of "freebies" in the educational, labor and consumer sectors, and moral and ethical context of "freebies" (Table 1).

Table 1. Sample of students in the survey

\begin{tabular}{|c|c|c|}
\hline Course of study & Female & Male \\
\hline 1 & 1 & 2 \\
\hline 2 & 1 & 1 \\
\hline 3 & 3 & 0 \\
\hline 4 & 1 & 1 \\
\hline 5 & 1 & 1 \\
\hline \multicolumn{2}{|c|}{ Total: 12 students } \\
\hline
\end{tabular}

The list of questions included the following:

1) What do you mean by "freebie"?

2) Who, in your opinion, is a "freeloader" (in Russian - "haljavshick")?

3) What features are inherent in "freebie" situations?

Situation 1: You walk down the street and see five hundred rubles. How will you behave and is it a "freebie"?

Situation 2: Five hundred rubles will fall out of a pocket of a person coming in front of you. How will you behave and is it a "freebie"?

Situation 3: You went into an empty classroom and see a hundred rubles lying on the desk. How will you behave and is it a "freebie"?

4) Do you know any superstitions about a "freebie" in your student life? And how do you feel about them?

5) Have you used these superstitions personally? If so, did they help you? dents?

6) How do you feel about "freeloader" stu-

7) What do you mean by "freebie" in terms of earnings?

8) What money do you call "free"?
9) Did you have a "free earnings"? Give an example.

10) From a moral point of view, is a "freebie" good or bad?

The conversation with each of the respondents took place in an informal setting (dormitory) starting from 03.30.2013 to 03.31.2013. Average duration of conversation was $25 \mathrm{~min}-$ utes.

\section{Discussion}

\subsection{Conception}

To start with, it was determined how respondents understood the "freebie" situation. It turned out that their common understanding of "freebies" is no different from the definition of "freebies" that was given earlier. The only addition is that $95 \%$ of respondents drew a parallel between "freebie" and luck. For few of them, the concepts are synonymous. For most, there is a difference due to the fact that luck is the result of a randomly obtained positive difference between the expected and actual outcome of the situation. According to respondents, sometimes a "freebie" can be prepared. For example, if you are preparing for the exam satisfactory, then the probability of getting a good or excellent mark is higher comparing to the situation of doing nothing. "There is a "freebie" that you prepare for yourself, that is, you will do something today, and tomorrow you will get some bonus for it, but there is a "freebie" that you don't expect at all, and it falls on you like snow on the head. This "freebie" can be called luck, that is how the second-year student determines the target phenomenon.

Respondents also identified specific features of situations that they could call "freebees". In their opinion, such a situation is characterized by luck, unpredictability, spontaneity and a minimum of one's own efforts. By all indications, this situation can be attributed to the subject of study of economists as an extreme case of maximization behavior.

\subsection{Beliefs and superstitions}

Further, the respondents were asked a series of questions regarding various beliefs about a "freebie", namely: do they know about existing rituals and do they use them. The list 


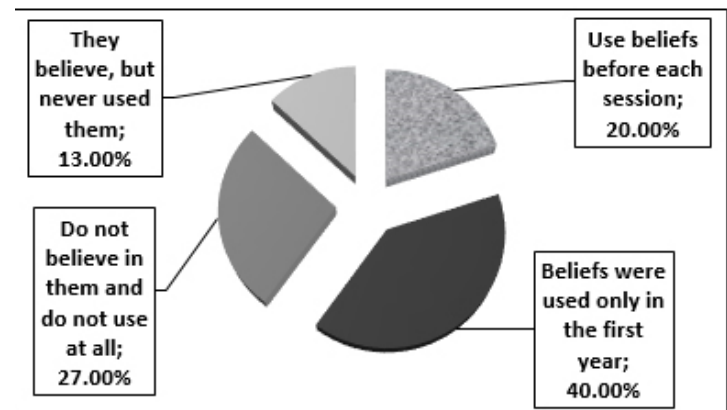

Fig. 5. The students' attitude to beliefs about "freebie" (\% of students)

of verified beliefs was borrowed from open sources on the Internet (see "Catch, "Freebie"! Or student superstitions" in References). It turned out that they knew everything about beliefs, but demonstrate different attitudes towards them. The results are presented in Fig. 5.

Someone uses them before each session; someone resorted to their help only in the first year of study. Students who are among those using beliefs before each session say this helps them calm down. Of cause, "freebie" does not add knowledge, but at the subconscious level this gives confidence in one's abilities. In the minority were those who are loyal to the "freebie" as such, but have never used it. The reason is that these people are used to reach goals with their own efforts and do not lay upon superstitions. They believe that those who receive their exams and tests for "free", lose a lot and in the future will not be able to achieve their goals. Most respondents used the "freebie" only in the first year, and then became disappointed in it.

\subsection{Earnings}

The next area of questions is earnings got in a "free" way. It turned out that "free money" or, in the terminology of respondents, "free, easy money", firstly, is money received in a very simple way with minimal effort. Secondly, the positive difference between the amount that they promised to be paid (students expected to receive) and the one that actually paid, can also be called a "freebie". And the last, "free earnings" is a bonus received for the work done earlier. During a conversation with one of the respondents, it was revealed that when making a decision, the value of the "freebie" is estimated. "For me to help to raise a cabinet to the second floor for five hundred rubles is a "freebie", but hand-bombing half a ton of coal for the same amount is no longer a "freebie", says a first-year student. This focuses on the subjective perception of both the presence and magnitude of the "freebie".

During a conversation with respondents, a very important pattern was revealed. Starting from the third year, that is, at a time when a student can get a job at least part-time, (s)he begins to perceive the financial assistance of his parents as a "freebie". First and second year students perceive this help as parental care.

\subsection{Moral issues}

One of the main issues in understanding the "freebie" phenomenon is its moral / ethical issue. The ethical idea in benefiting from "free" situations is a commonplace in any conversation with respondents. The general attitude of students to the "freebie" from the moral side can be expressed as follows: if the "freebie" does not harm anyone, does not happen at the expense of others, then there is quite appropriate. Some respondents indicated that this kind of "freebie" is even good, compared this behavior with an entrepreneurial functioning. One of the senior year respondents expresses it this way: "Free" strategy means that a person is looking to make things faster and to spend less energy while doing so; it's like in "Interns" (famous Russian TV show), when Bykov mixed buckwheat and rice and forced the interns to sort them out; the decision to buy a new pack- 
age of rice and a package of buckwheat did not harm anyone". Thus, we can conclude that students perceive strategies that are Pareto improvements as a positive "freebie". Most students recognized as inadmissible the systematic behavior aimed at obtaining a «freebie» by causing harm to others.

The personality of the "freeloader" was subjected to discussion with students: a person whose dominant strategy is to search for situations with the presence of a "freebie" ("free" strategy). Naturally, the systematic receipt of a positive consumer surplus is possible only due to the non-receipt of the benefits of social interaction by other people who are forced to encounter a "freeloader". We can say that the "freeloader" lives at someone else's expense.

Two terms should also be distinguished "free rider" and "freeloader". A free rider receives the public good without directly harming other society members. A "freeloader" receives private goods either at the expense of others or as positive effects from the production of other private goods, or appropriates the loss of private goods from other market participants.

The students' attitude to the "freeloader" has a dual character. On the one hand, being a "freeloader" is good. If a person manages to achieve a result without making any special efforts, if (s)he finds a way out of any situation, albeit with the help of others, if he is always lucky, this is not so bad. Perhaps this is the path that will lead to success in life. But given the moral aspect of the problem, students understand the short-term nature of such a behavior strategy. Sooner or later, the "freeloader" is expelled from the gift exchange, subjected to ostracism, which significantly complicates his/ her life. By maintaining a "free" strategy as the dominant behavior, a person runs the risk of being isolated. "You can't live at the expense of others all the time and rely on luck. Living at the expense of others, a person turns into a parasite. And luck is a temporary matter, the odds can be against us at any moment."

In the survey, students were asked three situations.

1) You walk along the street and see five hundred rubles.
2) Five hundred rubles fall out of the pocket of the person walking in front of you.

3) You went into an empty classroom and see a hundred rubles lying on the desk.

In all three situations respondents were asked: What will you do? and Is it a "freebie"?

In the first situation, everyone clearly answered that they would take the money. But whether this is a "freebie" opinion were divided. Some claimed that, yes, this is a "freebie". Others said that this was just a coincidence, but this could not be called a "freebie". The third part of participants could not say for sure whether it was "a freebie" or luck, since the difference between these concepts is very small for them in this case.

In the second situation, no one had any doubts. All respondents showed themselves to be honest and decent people - without any doubt, they would return the money to a passerby. They didn't attribute this situation to either "freebie" or luck.

The third situation was the most controversial. The denomination of a banknote has a considerable influence on the decision to take or not to take money. If there were a hundred rubles, most of the respondents would not have taken this money, and some even tried to find the owner. But, if five hundred rubles will lie on the table, students begin to doubt. The following solution was proposed: if after a short period of time the owner does not come for them, the students, of course, will take them. But if the owner of the money still appears, then they will definitely give it back. And only a few said that they still would not take this money. Almost every student said that (s)he would try to find the owner of this money, but then (s)he caught himself thinking that if (s)he starts asking other students whose money it is, there may be many who want to receive it, that is, in other words - "freeloaders". What will mean the transfer of "freebie". Then, in order to expand this situation, respondents were asked to play the role of those same "freeloaders". Everyone answered unequivocally that they would not take advantage of such a situation. The transfer of "freebie" should be investigated in a separate study. 


\section{Conclusion}

It is normal to establish a zero price for free goods, but in practice there are situations when a zero price is set for an economic good. According to the results of the presented study respondents consider the situation with the presence of a perceptibly sufficient surplus (consumer or producer) to be "free", which is clearly of a probabilistic nature of occurrence. The presence of such a situation modifies the behavior strategies of individuals to the extreme - the appearance of a "freeloader", which is perceived ambiguously. If a positive effect arises due to the loss in the effectiveness of the functioning of social exchange, the behavior of the "freeloader" as well as the existence of the "freebie" itself is recognized as acceptable. If the equivalence of gift-exchange relations is violated, such behavior is suppressed, and the situation begins to be regulated by the social coercive mechanisms.

In the presented study, only a small part of the manifestations of the "freebie" in so- ciety was considered. In our opinion the answers to the following questions are quite promising:

1. Is it possible to combine a "freebie" for producers and recipients analogous to a market transaction?

2. How to practically determine the "freebie" value?

3 . Is it possible to transfer or sell a "freebie", and how to determine its price?

4. How to evaluate the flows of free "freebies" and assistance in social interaction?

"Freebie" or getting a product at a zero price is a stable part of social life. Due to non-market effects arising in this kind of transactions, the "freebie" falls out of visions of economists. But since the behavioral strategies of many individuals in the modern world are built taking into account this factor it is necessary to smoothly incorporate a "freebie" as a phenomenon into basic economic concepts, what we tried to undertake in the paper presented to the reader.

\section{References}

Ariely, D. (2007). Zero as a Special Price: The True Value of Free Products. In Marketing Science, 26 (6), 742-757.

Bronfenbrenner, M. (1962). The Scarcity Hypothesis in Modern Economics. In The American Journal of Economics and Sociology, 21 (3), 265-270.

Brynjolfsson, E., Collis, A., Diewert, W.E., Eggers, F. \& Fox, K.J. (2019). GDP-B: Accounting for the value of new and free goods in the digital economy. In WP National Bureau of Economic Research, w25695.

Chto oznachaet slovo «xali ava» [What does the word "freebie" mean] (2017). In Rambler.Novosti [Rambler. News]. Available at: https://news.rambler.ru/other/37516408-chto-oznachaet-slovo-halyava/ (accessed 12 August 2019).

Gal, M. \& Rubinfeld, D.L. (2016). The hidden costs of free goods: implications for antitrust enforcement. In Antitrust Law Journal, 80 (401), 14-44.

Helemendrick, S. (2008). Xâิ ava kak vedushchai a strategî a russkogo cheloveka [Freebie as a leading strategy of the Russian people]. In Internet-project InoSMI.RU. 02.06.2008. Available at: https://inosmi. ru/world/20080602/241704.html (accessed 12 August 2019).

Heyman, J., \& Ariely, D. (2004). Effort for Payment: A Tale of Two Markets. In Psychological Science, 15(11), 787-793.

Moiseenko, E. (2012). Lovis', Xali ava! Ili studencheskie sueverî a. [Catch, Freebie! Or student superstition]. In Alma Mater: Magazine of Tomsk State University. 13.06.2012. № 2523. Available at: http:// almamater.tsu.ru/show_story.phtml?nom=2523\&s=5474 (accessed 12 August 2019).

Ryzhkova, M.V. (2013). Vozmozhnosti teorii ozhidaemoǐ poleznosti v opisanii potrebitel'skogo vybora [Expected Utility Theory and Consumer Choice]. In Izvestii a TPU [Bulletin of the Tomsk Polytechnic University], 322 (6), 65-70.

Shmakov, A.V., \& Bulgakova, E.A. (2011). Ispol'zovanie mekhanizma kompensa sii v grazhdanskom prave [The use of the compensation mechanism in civil law]. In TERRA ECONOMICUS, 9(4), 65-76. 


\title{
Экономическая природа феномена «халява» в среде российских студентов
}

\author{
М.В. Рыжкова а,б, Д.В.Алимова \\ ${ }^{a}$ Национальный исследовательский \\ Томский государственный университет \\ Российская Федерачия, Томск \\ ${ }^{6}$ Национальный исследовательский \\ Томский политехнический университет \\ Российская Федерачия, Томск
}

\begin{abstract}
Аннотация. Статья посвящена проблемам поведенческой экономики в части изучения особенностей социально-экономических отношений, возникающих в случае товаров с нулевой ценой в их особой форме - «халяве» - как особой форме бесплатного (или почти бесплатного) получения товара. Исследование показало связь между экономическими и неэкономическими товарами. Дано определение понятию «халява» - ситуация получения товара, при которой физическое лицо (получатель) несет нулевые или незначительные экономические или физические издержки при высокой оценке полезности товара. Были рассмотрены три ситуации: получателем товара является потребитель, работник и особый случай работника - студент, получающий оценки в учебном процессе. Рыночные излишки в этих ситуациях анализированы в терминах «халява» и «чистая халява». Было проведено глубинное интервью среди студентов, которое показало, что $95 \%$ респондентов проводят параллель между «халявой» и удачей, но «халява» может быть подготовлена. Интересным фактом является то, что деньги родителей с третьего курса воспринимаются студентами как «халява», а на младших курсах - как помощь. При изучении вопроса о морали в ситуации «халява» выяснено, что если «халява» никому не причиняет вреда, то это явление допускается и, более того, сравнивается с предпринимательской деятельностью. Были также проанализированы такие явления, как «свободные деньги» и «халявщик» как стабильная стратегия поиска бесплатных товаров. Последний вариант был отрицательно оценен респондентами. В заключении даны возможные дальнейшие направления исследования этого явления.
\end{abstract}

Ключевые слова: поведенческая экономика, экономические блага, неэкономические блага, бесплатные товары, экономические издержки, «халява», «халявщики», избыток рынка, нравственность, этика.

Научная специальность: 08.00.00 - экономические науки. 